\title{
SULPHURIZATION OF CORDIERITE, MINAS DA PANASQUEIRA, PORTUGAL
}

\author{
A. H. CLARK \\ Department of Geological Sciences, \\ Queen's University, \\ Kingston, Ontario.
}

\begin{abstract}
Iron-magnesium cordierite in the metasomatized contact hornfelses of the mineralized Panasqueira granite has been converted to the assemblage: $\mathrm{Mg}$-cordierite, andalusite, quartz, magnetite, and pyrite and/or arsenopyrite. This reaction is considered to demonstrate the geological feasibility of Kullerud and Yoder's (1964) experimental sulphurization of cordierite.
\end{abstract}

Although Kullerud and Yoder (1964) and, more recently, Kullerud (1967) have advanced the "sulphurization» of iron-magnesium cordierite to yield an iron-poor magnesian phase as a potentially valuable indicator of sulphide mineralization, the geological incidence of this reaction has yet to be adequately demonstrated. The metasomatized contact hornfelses of the Hercynian granitic cupola exposed in the Panasqueira tungsten mine, Beira Baixa, Portugal (Clark, 1964), are considered to exhibit a probable example of this process.

The mineral assemblages developed through contact metamorphism and metasomatism of the Infracambrian Beira Series phyllites in the immediate vicinity of the intrusion have been described in some detail (Clark, 1960). Emplacement of the granite was accompanied by the formation of biotite-cordierite-plagioclase $\left(\mathrm{An}_{10-15}\right)$ horn- felses, lacking $\mathrm{Al}_{2} \mathrm{SiO}_{5}$ polymorphs, and grading outwards to spotted chloritic phyllites. The pervasive syn- or immediately post-intrusion greisenization of the apical zone of the cupola also affected the thermal aureole, and xenoliths within the granite and a restricted contact zone, generally less than one metre in width, were converted to rocks consisting almost entirely of muscovite and quartz. Metamorphic biotite and cordierite were both largely destroyed at this time, but are locally preserved at the immediate intrusive contact in many zones.

That the greisenizing fluids, whatever their origin, contained sulphur, is shown by the sporadic development of disseminated pyrite, minor pyrrhotite, molybdenite (rhombohedral), arsenopyrite, chalcopyrite, and sphalerite in the greisen and in the metasomatized hornfelses. The sulphur was probably derived in part from the endo- 
blastic breakdown of early-formed accessory pyrite and pyrrhotite in the granite. Also introduced into the contact hornfelses were apatite, carbonates, cassiterite, Ti-oxides, and rare orthoclase, fluorite and tourmaline, all of which also crystallized contemporaneously in the intrusion.

In xenoliths and in the host rocks of the intrusion the contact metamorphic cordierite poikiloblasts $(0.5-8 \mathrm{~mm}$ in diameter) served as sites for the blastic growth of muscovite and quartz during metasomatism, and these minerals form mosaics pseudomorphing the original cordierite grain form. Some at least of the iron released in this alteration was apparently »fixed» as minute granules of magnetite, which form dusty halos surrounding the former poikiloblasts. Iron sulphides are generally rather sparse in such greisenized zones, whereas the original hornfelses contain abundant pyrite, the contact metamorphic equivalent of the assemblage: pyrite- monoclinic pyrrhotite, which characterizes the greenschist-facies Beira Series phyllites over large areas of northern Portugal.

In many parts of the contact aureole, however, extensive nucleation of sulphide minerals has occurred within remanent cordierite patches (Clark, 1960). Such inclusions are not observed in unmetasomatized hornfelses, and are regarded as having formed during greisenization, the sulphur having been in part introduced by the metasomatizing fluids, and in part derived from breakdown of contact metamorphic pyrite. Euhedral porphyroblasts of pyrite and, commonly, arsenopyrite, crystallized within former cordierite poikiloblasts, and attained considerably larger dimensions than the sparse disseminated sulphide in the rock matrix. The quantity of pyrite and arsenopyrite in several specimens of contact hornfels appears to be a direct function of the former proportion of cordierite grains, and the association of the sulphides with this silicate or its alteration products is evident in handspecimen.

The sulphide inclusions in former cordierite areas are consistently associated with aggregates of equidimensional quartz grains, with euhedralto-subhedral magnetite $\left(\mathrm{Fe}_{2} \mathrm{TiO}_{4}<0.1 \%\right.$; the magnetite occurring in the unmetasomatized hornfels is slightly richer in Ti), minute acicular crystals of andalusite, and ill-defined "spongy» areas of a cordierite which has optical properties distinct from those of the original mineral. The relative proportions of sulphide and of these associated minerals vary widely in individual sections, and one or more of the latter are apparently absent in several smaller areas; these variations may, however, merely reflect the random intersection of the section surface with the poikiloblastic nuclei. These minerals form intergrowths, with little internal textural regularity, which occupy the original volumes of the cordierite poikiloblasts.

Occasionally, only restricted zones of individual corderite grains have been affected by this alteration, and, in such cases, the contact metamorphic cordierite may be directly compared to that formed together with the sulphide inclusions. Direct correlation of the optical properties of cordierites with composition is rarely possibly (Deer, Howie and Zussman, 1962), but the later, fine-grained generation is seen to have markedly reduced refractive indices and birefringence when compared to the earlier. Such a change would not be in conflict with a decrease in the iron: magnesium ratio of the cordierite. In several sections, the original unaltered cordierite, particularly where showing well-defined sector twinning, exhibits a marked inhomogeneity owing to the occurrence of zones of a differing birefringence, arranged concentrically or in conformity with the twin segments. In such grains, the metasomatic sulphide and associated minerals have preferentially developed in the zones of higher birefringence, and, probably, higher iron content.

Qualitative electron microprobe scans for $\mathrm{Fe}$ $\mathrm{K} \alpha$ have been carried out across adjoining areas of the early and late cordierite in polished section, and demonstrate clearly the markedly lower iron content of the latter. Very approximately, 
some 80 per cent of the original iron content of the cordierite was released in its breakdown. Using the associated magnetite as a rough internal standard, it is estimated that the $\mathrm{FeO}$ content of the cordierite was reduced from ca. 7 weight per cent to ca. $1-2$ per cent. The fine-grained cordierite occurring with pyrite (or arsenopyrite), magnetite, andalusite, and quartz alone has approximately the same iron content as that in contact with original cordierite, but the late generation exhibits highly irregular, and abrupt, smallscale variations in its $\mathrm{Fe}: \mathrm{Mg}$ ratio.

Both andalusite (ca. $0.1-0.2$ weight per cent $\mathrm{Fe}_{2} \mathrm{O}_{3}$ ) and the iron-poor cordierite are absent in the vicinity of cordierite poikiloblasts which have been replaced by muscovite, although as noted above, quartz and, peripherally, magnetite are present in such zones. It is suggested, therefore, that the association of the sulphide porphyroblasts with the assemblage: iron-poor cordierite, andalusite, magnetite, and quartz, is of significance, and it is evident that this assemblage is closely similar to that produced by Kullerud and Yoder (1964) in their experimental sulphurization of an intermediate, iron-magnesium cordierite. These authors found that such a cordierite was readily converted to a magnesian cordierite, pyrrhotite and/or pyrite, magnetite and/or hematite, sillimanite or mullite, quartz, and $\mathrm{SO}_{2}$ by reaction with sulphur at $650^{\circ} \mathrm{C}$ under 2.000 bars pressure, the nature of the iron sulphides and oxides depending on the initial concentration of sulphur. Experiments in rigid silica glass tubes at $500^{\circ} \mathrm{C}$ suggested that similar reaction products would be formed in the presence of vapour at this lower temperature.

The latter temperature is probably not far in excess of that prevailing during the greisenization of the Panasqueira granite and contact hornfelses. The co-existence of pyrite and arsenopyrite in the replacement assemblages implies temperatures of less than $491 \pm 12^{\circ} \mathrm{C}$ at $<1$ bar (Clark, L. A., 1960). This metasomatic arsenopyrite has $\mathrm{d}_{131}=1.6326-1.6330 \pm 0.0003 \AA$ (seven determinations on material from four hand-specimens), and has, therefore, approximately the same arsenic: sulphur ratio as the late-stage arsenopyrite in the mineralized veins, being appreciably richer in sulphur than the early hydrothermal arsenopyrite (Clark, 1964). Even at low confining pressures, arsenopyrite of this composition could not have crystallized below approximately $400^{\circ} \mathrm{C}$, if equilibrium with pyrite was attained. The marked effects of confining pressures on the steep solvi bounding the arsenopyrite stability field in the system $\mathrm{Fe}-\mathrm{As}-\mathrm{S}$ prohibit more precise temperature estimation (Clark, L. A., 1960). The development of andalusite in the place of sillimanite would be expected at temperatures in this approximate range and under low pressures; the confining pressure at the time of the alteration was probably considerably below 2.000 bars.

It is considered that the assemblages briefly described in this note were formed through the sulphurization of cordierite in essentially the way outlined by Kullerud and Yoder (1964). The development of arsenopyrite, with or without pyrite, in many of the observed replacement loci suggests that breakdown of iron-bearing silicates is as readily accomplished by the action of fluids bearing arsenic and sulphur as by those with sulphur alone (this process might be termed sulpharsenization, but perhaps such usage should not be encouraged). The reaction involved in the breakdown of the cordierite may be broadly expressed as: $\mathrm{FeMgAl}_{4} \mathrm{Si}_{5} \mathrm{O}_{18}+\mathrm{S}+\mathrm{As} \rightarrow$ $\mathrm{Mg}_{2} \mathrm{Al}_{4} \mathrm{Si}_{5} \mathrm{O}_{18}+\mathrm{FeS}_{2}+\mathrm{FeAsS}+\mathrm{Fe}_{3} \mathrm{O}_{4}+$ $\mathrm{Al}_{2} \mathrm{SiO}_{5}+\mathrm{SiO}_{2}$ (cf. Kullerud and Yoder (1964); in the absence of quantitative determination of the actual proportions of the reaction products in the alteration zones, any attempt to »balance». this equation would be unwise). No hydroxylbearing silicates are systematically associated with the alteration assemblages, and the hydroxyl component of the original cordierite was probably retained by the late cordierite.

In view of the widespread introduction of pyrite and arsenopyrite into the contact hornfelses, 
$\mathrm{t}$ is surprising that there is no microscopic evidence for the sulphurization of the locally- abundant biotite, to yield, for instance, an oxymica (Kullerud, 1967). The biotite in these rocks has suffered extensive replacement by muscovite, often with the development of intervening dullgreen reaction zones, having weak birefringence and pleochroism, and containing segregations of iron- and titanium oxides, but biotite-sulphide contacts are sharp and exhibit no evidence of reaction.

The sulphurization of cordierite in contact aureoles of the Panasqueira type is probably unlikely to have played a significant role in the development of sulphide orebodies. In fact, the fixation of the sulphur transported by postmagmatic hydrothermal fluids by iron-bearing silicates such as cordierite and biotite in thermal aureoles to form low-grade or barren disseminations may actually diminish the probability of the formation of economic concentrations of the ore metals in vein deposits. Under exceptional circumstances, however, the sulphurization of closely-spaced ferromagnesian crystals in some contact rocks, such as andesite, might constitute the first stage in the development of contact metasomatic orebodies.

The presence of unusually magnesian cordierites in the host rocks of plutons could serve as an indication of the former activity of sulphurbearing fluids, and, hence, point to the potential occurrence of mineralization in the vicinity. However, there is as yet no evidence that, under contact metasomatic conditions, the sulphide produced through sulphurization of cordierite has crystallized beyond the original reaction zone. The «exploration target» has probably, therefore, been little enlarged through sulphurization, and disseminated sulphides are certainly more conveniently detected in the course of exploration than are magnesian cordierites. It is considered, however, that the Panasqueira assemblages demonstrate the feasibility of the sulphurization of cordierite under geological conditions, and this reaction may have taken place on a considerably larger scale in the case of strata-bound base metal deposits which have been metamorphosed together with metasomatic envelope rocks rich in cordierite or where cordierite was formed by regional metamorphism, (e.g. Orijärvi, Finland, or Bodenmais, Germany; Schreyer, Kullerud and Ramdohr, 1964). Detailed study of the compositional variations of cordierite in such mineralized environments might lead to the development of a useful exploration tool, based on, for instance, the change in the refractive index of cordierite in the host rocks.

\section{REFERENCES}

Clark, A. H. (1960) Contributions to the geology of the Panasqueira region, Beira Baixa, Portugal. Unpublished B. Sc. thesis, Univ. London.

- (1964) Preliminary study of the temperatures and confining pressures of granite emplacement and mineralization, Panasqueira, Portugal. Trans. Inst. Min. Metall., v. 73, pp. 813-824.

Clark, L. A. (1960) The Fe-As-S system: variations of arsenopyrite composition as functions of $\mathrm{T}$ and $\mathrm{P}$. Rep. Dir. Geophys. Lab., 1959-1960, pp. 127-130.

Deer, W. A., Howie, R. A., and Zussman, J. (1962) Rock-forming minerals, vol. 1, Longmans, London.
Kullerud, G. (1967) Sulfide studies. in Researches in Geochemistry, Vol. II, Wiley, New York, pp. 286321.

- and Yoder, H. S., Jr. (1964) Sulfide-silicate reactions. Rep. Dir. Geophys. Lab., 1963-1964, pp. 218-222.

Schreyer, W., Kullerud, G., and Ramdohr, P. (1964) Metamorphic conditions of ore and country rock of the Bodenmais, Bavaria, sulfide deposit. N. Jb. Miner., Abh., Bd. 101, pp. 1-26.

Manuscript received, February 12, 1969. 